\title{
Fastighetsskötares erfarenheter av validering
}

\author{
(Caretakers' experiences of validation)
}

Per Andersson

Linköpings universitet, Sverige (per.andersson@liu.se)

\begin{abstract}
Validation, or recognition of prior learning, involves an idea of 'making learning visible' - of valuing knowledge irrespective of how, when and where it is learnt. This chapter presents a phenomenographic analysis of how a group of caretakers from a Swedish property management company experience participation in a validation initiative focusing on their vocational competence.

The findings show how validation is experienced in various ways by the caretakers as an opportunity for personal development, as a matter of assessment and control, or as 'only scratching the surface'. The process is also experienced in different ways in terms of learning - with a focus on prior learning or new learning, or even no learning. Other benefits of validation are described in terms of exchange value or personal development. Through a contextual analysis, the findings are integrated in a model where the relationship between the individual and the validation process is described as a developmental, a credit-exchange or a critical relation.

The conclusions put focus on the relevance of validation for groups like caretakers. This is a group where the vocational learning to a high extent is informal, which means a potential for recognition of their prior learning in terms of formal credentials.
\end{abstract}

Keywords: recognition of prior learning, validation, vocational competence, phenomenography, contextual analysis

NJVET, Vol. 10, No. 3, 29-44 Peer-reviewed article doi: 10.3384/njvet.2242-458X.2010329 


\section{Introduktion}

Validering är en företeelse som har diskuterats och utvecklats främst under de senaste decennierna, i Sverige såväl som i andra länder. Validering kopplas i första hand till vuxnas lärande, och då i stor utsträckning vuxnas yrkeskompetens. Det handlar om att "göra lärande synligt" ("making learning visible", Bjørnåvold, 2000). Synliggörandet innebär en ambition att identifiera kunskapers rättmätiga värde, oberoende av hur, var och när de har utvecklats. Olika begrepp används i olika länder och sammanhang, ibland med fokus på processen validering, ibland med fokus på kunnandet - tidigare lärande eller reell kompetens, och ibland används begrepp som innefattar båda dessa aspekter. På engelska är recognition, validation, accreditation eller assessment of prior (experiential) learning de vanligaste begreppen, nästan alltid med prior learning som en del av uttrycket. I Norden talar man bland annat om realkompetencer och realkompetencevurdering (Danmark), realkompetanse och realkompetansevurdering (Norge), raunfxrni och raunfxrnimat (Island), samt aiemmin opitun tunnistaminen ja tunnustaminen ("värdering av vad som har lärts" eller "erkännande och validering av tidigare lärande") (Finland) (Hult \& Andersson, 2008). Begreppet validering som används i Sverige är en översättning från franskans validation (des acquis de l'experience), likväl som när validation används i denna betydelse på engelska. I denna svenskspråkiga artikel används begreppet validering, som för övrigt introducerades med denna innebörd i Sverige 1996 i Kunskapslyftskommitténs första delbetänkande (SOU 1996:27).

Artikeln bygger på en fenomenografisk analys av en grupp svenska fastighetsskötares erfarenheter från när de deltog ett initiativ för att validera deras yrkeskompetens inom områden som trädgårdsskötsel och städning. ${ }^{1}$ Fastighetsskötare är ett yrke där det under lång tid inte funnits någon särskild yrkesutbildning, och där det därför finns många yrkesverksamma som saknar en specifik utbildning för yrket. Många har lärt sig yrket informellt, i arbetet, och en del har en utbildning inom något av de många områden som inryms i yrket - förutom trädgårdsskötsel och städning kan arbete med underhåll och reparationer ge användning för kunskaper från yrken som byggnadsarbetare, elektriker och VVS-tekniker ("rörmokare" som arbetar med värme, ventilation, sanitet). Denna bakgrund, med mycket informellt lärande inom yrket, var en huvudsaklig anledning till att validera fastighetsskötarnas yrkeskompetens, och en bakgrund med informellt lärande var också det vanligaste bland deltagarna i det aktuella initiativet, vilket illustreras av följande citat:

\footnotetext{
Det är nog mest man har blivit upplärd på arbetet sedan man började för länge sedan som en lite sommarjobbare och så vart man lite vikarie. Sen har vi ju fått lite utbildningar efter hand om man säger. Den biten har vi väl haft ganska stor inverkan på vad vi vill utbilda oss, vi har ju såna här personliga samtal och grejor och då kan vi lägga fram vad vi känner att man, jag vill lära mej lite mer om el och jag vill lära mej mer och det och det och så. Sen har man tagit hänsyn till det. Jag har inte gått nån sån ja fastighetsskötarutbildning.
} 
Alla deltagare var anställda i samma fastighetsbolag, och arbetsgivaren stod för kostnaden för valideringen. Inledningsvis gjordes en kartläggning av individens kompetens genom ett diagnostiskt samtal. Den valideringsprocess som sedan följde innehöll en kombination av skriftliga, muntliga och praktiska prov, som genomfördes under ett antal dagar utspridda under en femmånadersperiod. Den inledande kartläggningen låg till grund för beslutet om vilka "ämnen" som valideringen skulle omfatta för varje individ. De områden som kunde ingå var städning, trädgårdsskötsel, byggnader, datorer och miljö. De som klarade valideringen med godkänt resultat fick ett certifikat på kompetensen inom respektive område. Efter valideringsprocessen erbjöds fastighetsskötarna fortsatt kompetensutveckling baserat på de behov som valideringen hade synliggjort, och denna kompetensutveckling kunde leda fram till ett certifikat som omfattade alla kompetensområden som ingick.

\section{Perspektiv på validering}

Parallellt med att validering har utvecklats som en företeelse inom policy och praktik i relation till livslångt lärande i många länder har även forskningen på området växt fram runt om i världen. Till att börja med var forskningen nära knuten till den praktiska utvecklingen av hur validering skulle gå till. Så småningom utvecklades mer kritiska och teoretiskt baserade förhållningssätt inom forskningen. För den som vill få perspektiv på forskningsområdet finns bland annat en "trilogi" av antologier. Andersson och Harris (2006) presenterar ett antal kritiska, teoretiska perspektiv som använts för att förstå validering som företeelse. Harris, Breier och Wihak (2011) sammanställer översikter över forskningsläget i olika delar av världen, vilket också visar att den svenska forskningen är relativt framträdande på området (Andersson \& Fejes, 2011). I den tredje antologin knyter Harris, Wihak och Van Kleef (2014) tillbaka till praktiken genom forskningsöversikter baserade på olika centrala teman och tillämpningsområden - exempelvis kvalitet, social rättvisa, yrkesutbildning, arbetsliv och högre utbildning - vilka även inkluderar implikationer för de praktiska tillämpningarna.

En översikt över den svenska valideringsforskningen, baserad på vilka teoretiska perspektiv som tillämpats, görs av Andersson och Fejes (2014). Där är huvudtemana validering och lärande, validering och makt, valideringens potentiella kraft samt valideringens validitet och reliabilitet. I det första temat innefattas studier med fokus på validering som lärandepraktik och på validering som uppfattat fenomen, och det sistnämnda är det område där den studie som ligger till grund för den här artikeln hör hemma. Det finns även bland annat några nordiskt baserade antologier inom området. I Danmark finns ett kunskapscentrum för validering, där flera texter har getts ut, däribland en antologi med dansk och internationell medverkan (Aagaard \& Dahler, 2011). Vidare har en grupp finska 
forskare varit involverade i arbetet med en internationell antologi med fokus på validering (Halttunen, Koivisto \& Billett, 2014).

Under utvecklingen av valideringsområdet har ett otal modeller utvecklats och beskrivits i olika länder. Ett sätt att sortera dessa modeller är att skilja mellan systemanpassad respektive systemförändrande validering (Andersson, Sjösten \& Ahn, 2003). Systemanpassad validering handlar i stor utsträckning om konvergent bedömning (Torrance \& Pryor, 1998) av kunskap och kompetens, till exempel en kompetensbaserad bedömning där fokus ligger om en individ har vissa kunskaper och färdigheter och kan uppfylla specifika kriterier. Detta kan jämföras med en divergent bedömning (Torrance \& Pryor, 1998), där det är vad individen kan som utforskas på ett mer förutsättningslöst sätt. Systemförändrande validering använder divergenta bedömningsmodeller i större utsträckning, vilket också betyder att det som individer redan kan ligger till grund för att förändra systemen på arbetsplatser, i skolor etc.

Andra sätt att beskriva skillnaden mellan olika ansatser är dikotomin mellan meritinriktade och utvecklingsinriktade modeller (Butterworth, 1992), och kategoriseringen i tekniska/marknadsinriktade, liberala/humanistiska samt kritiska/radikala perspektiv (Breier, 2005). Sammanfattningsvis kan man säga att synliggörande av (informellt) lärande har en potential att förändra system, men att en erkännande- eller valideringsprocess också kan innebära en mer eller mindre avsiktlig anpassning till systemet.

\section{En fenomenografisk studie}

Den studie som ligger till grund för den här artikeln syftade till att beskriva och analysera variationen i sätt att erfara validering, som denna uttrycktes av deltagare i en satsning på validering för fastighetsskötare. I studien av dessa fastighetsskötares sätt att erfara validering användes som nämnts en fenomenografisk ansats (Bowden \& Walsh, 1994; Marton, 1981, 1988; Marton \& Booth, 1997), som även innefattade en kontextuell analys (Svensson, 1976). Den fenomenografiska ansatsen innebar att jag i analysen sökte efter uppfattningar eller sätt att erfara några olika fenomen inom ramen för valideringsverksamheten, vilka presenteras i kategorisystem eller "utfallsrum", och den kontextuella analysen identifierar relationer mellan kategorier inom och mellan kategorisystemen.

Fenomenografin innefattar en icke-dualistisk ontologi. Vårt sätt att erfara ett fenomen eller en situation ses därmed som en internal relation mellan världen och oss, och den enda värld vi då har tillgång till är vår uppfattade värld. Omfattande empirisk forskning har visat att det finns ett begränsat sätt att erfara ett fenomen. Fenomenografin fokuserar på variationen i sätt att erfara något, och denna variation är relaterad till å ena sidan vår förmåga att samtidigt urskilja och vara medvetna endast om ett begränsat aspekter av ett fenomen eller en situation, 
och å andra sidan den mening som vi tilldelar dessa aspekter och relationerna mellan dem.

Analysen baseras på intervjuer med elva fastighetsskötare, vilket var samtliga deltagare i den aktuella gruppen. Intervjuerna genomfördes efter att de hade deltagit i valideringsprocessen, men innan de hade erbjudits fortsatt kompetensutveckling. Intervjuerna var halvstrukturerade och täckte in följande områden: vilka ämnes/kunskapsområden som respektive deltagares validering omfattade; vad de tyckte att validering handlade om; vilken kunskap som hade bedömts, och inte bedömts; var de hade lärt sig sitt yrke; om något som de inte tidigare var medvetna om hade synliggjorts; och vad de i allmänhet hade fått ut av att delta i valideringen. Intervjuerna spelades in och transkriberades, och de utskrivna intervjuerna låg till grund för analysen. Resultaten presenteras i form av kategorier, som genom "idealtyper"2 beskriver variationen i sätt att erfara fenomen. Dessutom gjordes som nämnts en analys av relationer mellan kategorier, såväl inom som mellan kategorisystem. Citat från intervjuerna används som illustrationer av olika kategorier. Resultaten kan ses som utfallet av en tolkning, som min konstruktion av en beskrivning av relationerna mellan deltagarna och fenomenen (Walsh, 1994).

\section{Resultat - erfarenheter av validering}

Resultaten från studien tar upp erfarenheterna av validering från tre olika perspektiv. Först presenteras sätten att erfara själva valideringsprocessen. Därefter diskuteras erfarenheten av lärande inom ramen för valideringsprocessen. Det tredje perspektivet berör erfarenheterna av vad valideringsprocessen gett för utbyte av annat slag än lärande. Slutligen förs dessa tre perspektiv samman i en diskussion kring tre möjliga relationer mellan deltagaren och valideringsprocessen.

\section{Erfarenheter av valideringsprocessen}

Det första perspektivet som tas upp är alltså hur valideringsprocessen i sig erfors av deltagarna. Resultaten visar på tre olika sätt att erfara denna process:

A. Validering som ett tillfälle för personlig utveckling,

B. Validering som en fråga om bedömning och kontroll, och

C. Validering som något som "bara skrapar på ytan"

Fokus i den första kategorin, validering som ett tillfälle för personlig utveckling, är individen och hans eller hennes kunskap och utveckling. Genom valideringen blir deltagaren medveten om sin egen kunskap, vilket också ger förutsättningar för personlig utveckling. Man lär något genom valideringsprocessen, vilket samtidigt skapar förutsättningar för fortsatt lärande. Sammantaget så är det en 
positiv erfarenhet, även om det finns en medvetenhet om att allt man vet inte täcks i valideringen.

Det är att försöka få se vad jag kan tycker jag väl och vad jag inte kan. Och förkovra mej. Det är för min egen del, största målet är att förkovra sej, kanske få en bättre status och ett annat yrke också kanske i förlängningen. Annars ska man nog inte gå det här. Det är ju frivilligt naturligtvis. Men vi är några stycken utvalda så man känner sej lite priviligierad som fått gå det här.

Ja, det är för att få kunskap om vad vi kan egentligen va, och vad jag själv inte kan mycket också. Man kanske kan mer än vad man tror egentligen. ... Jo men jag gör det här för min egen skull, mycket bara för att få ner allting på papper också.

Valideringen är förstås också en fråga om bedömning, men denna aspekt är bara närvarande i bakgrunden i denna kategori, som något som gör kunskapen synlig för individen.

I kategorin validering som en fråga om bedömning och kontroll är det å andra sidan bedömningen eller snarare bedömaren som står i fokus. De huvudsakliga aspekterna i kategorin är individen själv, hans/hennes kunskaper, samt en extern aktör som bedömer och/eller kontrollerar. Relationerna mellan dessa aspekter varierar inom kategorin, vilket innebär att denna kan uttryckas på något olika sätt.

Det är väl att de vill kontrollera hur mycket man kan liksom eller vi kan visa vad vi kan rent ut sagt. Vad vi kan för något och vad vi tror oss kunna och vad vi verkligen kan egentligen. Det är att visa att man kan saker som man inte har utbildning på, tror jag.

Bedömningen är också relaterad till de möjligheter till fortsatt kompetensutveckling som kommer att följa efter valideringsprocessen. Det vill säga att valideringen kommer att leda till möjligheter till "personlig utveckling", men dessa möjligheter kommer efteråt och inte som en del av valideringen, och det är fortfarande bedömningen, som ska resultera i ett "papper", ett certifikat, som är det centrala i uppfattningen av själva valideringen.

Det går ut på att man testar sina kunskaper i olika ämnen och då är det satt en viss nivå vad man ska klara för att var godkänd eller icke godkänd, blir man inte godkänd så ska man få möjlighet att studera det då senare. De kommer ju att testa vilka ämnen vi inte är godkända i och sen är det meningen att vi ska få läsa in det då och bli godkända då va och sen i slutändan ska vi få ett papper, ett intyg på att vi är fastighetsskötare och att vi kan det här, vi är godkända inom de områdena då va. Och det är bra att vi får ett certifikat.

Vissa deltagare upplever att det finns problem med bedömningen. Det handlar om problem med nivån på den kunskap som bedöms, med de metoder som används, eller problem när det gäller vilket kunskapsinnehåll som täcks i bedömningen. Men de problem som uttrycks relaterade till denna kategori är konstateranden, som inte tolkades som uttryck för ett kritiskt perspektiv. 
Ja. Så jag menar sen har man ju chansat på frågorna med. Det är ju så, kan man inte så får man ju chansa, blir det rätt så blir det ...

Sammantaget är denna kategori uttryck för en ganska neutral erfarenhet av att bli bedömd och kontrollerad.

Att uppfatta validering som något som "bara skrapar på ytan" är däremot en erfarenhet som kommer till uttryck genom ett kritiskt perspektiv. Huvudaspekterna i kategorin är individens kunskap och de bedömnings/valideringsmetoder som används. Relationen mellan dessa uppfattas som problematisk, vilket resulterar i en negativ erfarenhet.

\begin{abstract}
Att kunna tjugo träd som vi har gjort idag, det känns ju lite, vad har jag för nytta av det. Jag måste ju veta vad egenskaperna, vad träden, vad de vill ha för jord, hur de ska beskäras och sånt. Det är inget sånt. Det är bara växtkännedom och det känns ju lite konstigt tycker jag. Så det är lite, det verkar lite hafsigt. Lite illa genomtänkt. Det är väl inte Trädgårdsskolans fel kanske men hela valideringen känns lite, snabbt, lite dåligt genomtänkt på något vänster känns det som.
\end{abstract}

Vi har ju gått igenom buskar, blommor och gräs och ja lite anläggning och lite men det känns bara som man har skrapat lite på ytan på något vänster, det känns lite.

Huvudtemat i kategorin är att valideringen inte gör rättvisa åt individens kunskap och kompetens. Det är en ny typ av bedömning, vilken uppfattas som en ad hoc-metod som huvudsakligen testar triviala kunskaper och förmågor. Deltagarna kan mycket mer än vad som bedöms - kunskaper som dessutom är mer centrala för yrket.

\title{
Erfarenheter av lärande i validering
}

Det andra perspektivet $\mathrm{i}$ analysen av erfarenheter av validering är ett lärandeperspektiv. Hur uppfattas valideringsprocessen i termer av lärande? Variationen innefattas här i tre huvudkategorier, som beskriver olika sätt att uppfatta hur lärande är relaterat till validering:
A. Validering innebär inte något lärande,
B. Validering handlar om tidigare lärande, och
C. Validering innebär även nytt lärande

I den första kategorin ger deltagaren uttryck för erfarenheten att validering inte innebär något lärande. Certifiering genom validering innebär inte att du kan mer än vad du kunde tidigare. Deltagarens uppfattning är att deltagandet inte har gett något i detta avseende.

Det här tror jag inte ger någonting i och för sej men. Jag kan ju inte mer, även om jag blir godkänd häruppe så kan jag inte mer än jag liksom kunde, eller när jag kom i morse om man säger då. Jag kan inte mer idag även om jag blir godkänd. Jag är inte fullärd i det här om man säger. 
Ett annat slags erfarenhet av lärande i relation till validering sätter fokus på tidigare lärande. Denna uppfattning är närvarande i det perspektiv med fokus på bedömning och kontroll som diskuterats ovan. Tidigare lärande, eller kunskap, finns här implicit som objektet för bedömning och kontroll, men detta uppfattas inte som att lära någonting.

För några deltagare betydde valideringsprocessen emellertid nya sätt att erfara deras tidigare lärande. En medvetenhet om vad du faktiskt kan är något som kan utvecklas, du inser med andra ord vilka kunskaper du redan har. Detta innebär en metaprocess där du lär dig något om ditt tidigare lärande, men detta uppfattas inte som nytt lärande.

Ja, det är väl, man märker rätt snabbt att man vet ju rätt mycket som man inte trodde att man visste egentligen eller så men man vet ju ganska mycket om mycket och det är ju bra. Så att jag känner väl att jag har väl ett hum om det mesta som jag har bestämt att jag ska validera mej i. Så har jag ju det mesta kan jag nog rätt mycket bra, det som jag arbetar med dagligen då.

Valideringsprocessen kan också uppfattas som ett tillfälle där man får friska upp kunskaper man redan hade.

Fastighetsskötaren: På 80-talet höll vi på och la lite plattor och sådär men det är inget vi gör idag. Så det är nyttigt att kunna.

Intervjuaren: Ja, var det så att du kunde det sen dess och fick friska upp det lite? Fastighetsskötaren: Ja, jag hade lite hum om det. Somliga kunde ingenting. Så det var ju bra.

Den tredje kategorin när det gäller erfarenheter av lärande i validering lyfter fram att validering även kan handla om nytt lärande. Processen kan bland annat innebära att du lära dig eller snappar upp saker då och då, oplanerat och informellt.

Det har gett rätt mycket. Man har ju lärt sig mycket som man inte visste innan, också.

Denna informella process uppfattas inte nödvändigtvis som "lärande", även om man har snappat upp något - något som uttrycks i följande citat.

Ja, det är väl, vad ska man säga, lite har man väl snappat upp som man inte visste innan och men ja i stort sett så har jag ju jag vet inte, man har inte lärt sej något som "det här kunde jag inget om förut liksom" utan inga direkta på det viset, planet men å andra sidan är det här bara en validering på det jag kan så i det här skedet ska jag egentligen inte lära mej så mycket utan jag ska bara försöka visa.

De ovanstående exemplen på "nytt lärande" innebär att det är individer som snappar upp saker. Men det finns också erfarenheter av kollektivt lärande. Då valideringsprocessen är organiserad i grupp finns det möjlighet att lära av varandra under processens gång.

Nej, utan vi lär oss av varandra tycker jag, man går och pratar och snackar med lärarna och varann också. De är frăn [Småstad] och de träffar vi inte varje dag precis. De jobbar på ett annat sätt. 
Det lärande som skett genom valideringen uttrycks också som attityder - ett intresse har utvecklats, och därigenom också en vilja att lära mer.

\begin{abstract}
Ja, det har väl gett mej mer intresse för vad buskar och träd heter. Förut har man bara kunnat det vanligaste. Nu har man fått lära sej lite mer ovanliga så man blir lite mer intresserad av konstiga, för det finns en massa ovanliga saker och ting. Man kan ju alla vanliga men man blir mer intresserad av att lära sej vad alla heter nu även vad konstiga buskar och träd som man inte har i områdena och så som man vill lära sej.
\end{abstract}

Organiseringen av den valideringsprocess som dessa fastighetsskötare deltog i innebar också att deltagarna skulle fortsätta att studera delar av den yrkeskunskap som inte täcktes av valideringsprocessen. Detta slags erfarenhet är förhållandevis formell - det följande uttrycket ligger nära det officiella målet och planen för satsningen, där fortsatt kompetensutveckling för fastighetsskötarna är en del av "paketet".

Ja, man får verkligen se vad man kan och så. Och så får man chans till vidareutbildning om man vill söka något annat jobb så har man kompetensen och man kan i stort sett allting. Det är bra.

\title{
Andra former av utbyte av validering än lärande
}

Utbytet av att delta i validering uttrycks inte bara i form av lärande, utan deltagarna uttryckte även uppfattningar av annat slags utbyte. Variationen innefattas här i följande kategorier, som beskriver två olika sätt att uppfatta sådant utbyte av att delta i validering:

A. Deltagande i validering har ett bytesvärde, och

B. Deltagande i validering innebär personlig utveckling

Bytesvärdet uttrycks på olika sätt. Ett viktigt utbyte är det värde valideringen har om du söker nytt jobb. Detta värde knyts huvudsakligen till resultatet i form av en certifiering.

Det, den kan ge i slutändan egentligen för ens egen skull, är ju att man får den här valideringen, att det bli ett intyg på något sätt, man kan visa upp antar jag. Då kan det vara bra om man ska söka andra jobb egentligen för att visa sin kunskapsnivå. Annars jobbmässigt sett såhär tror jag inte det gör någon skillnad, det man har så att säga. Det är nog bara egentligen bara om man ska söka något jobb.

Deltagandet kan också uppfattas ge bättre möjligheter att behålla din position i organisationen, att behålla ditt jobb. Och dessutom kan det resultera i högre status inom företaget.

Här satsar ändå företaget på en, det kostar ju mycket pengar och sånt härn’t då va så att, jag menar tror företaget på en så, vi söker ju ett antal personer så vart man uttagen då så att säga så jag menar då är företaget mån om en, de som blir utvalda av alla som sökte då va. Då vill de ju satsa på en så på så sätt tycker jag att det är respons från företaget med att de vill satsa på en, man har många år kvar i företaget, man vill ha en kvar liksom. Det är väl en del av det också då. 
Det finns också mer kritiska perspektiv när det gäller bytesvärdet, men där ändå detta värde är i fokus. Ett exempel är när processen beskrivs som intressant, men där bytesvärdet (hos ett "papper") ändå verkar tveksamt.

Intressant har det varit men jag vet inte om jag kommer längre i mitt jobb bara för att jag bevisar vad jag kan på något sätt. För sedan får man bara ett papper på vad man kan.

En annan "kritisk" uppfattning uttrycks som att bytesvärdet främst är en fråga för företaget. När arbetsgivaren kan säga att "vi har certifierad personal" så kan företaget tjäna på detta.

... för företagets sida är det bra kanske att man kan marknadsföra sej med validerad personal kanske då...

Deltagandet i valideringen kan också leda till personlig utveckling som innefattar andra aspekter än lärande. Erfarenheten av att känna sig priviligierad, att deltagandet är en belöning, en lyx och ger en "kick", kan förstås i ljuset av att endast en begränsad del av de anställda hade getts tillfälle att delta i den här valideringsprocessen.

Det här avbräcket det känns som ett litet lyx att få gå här istället för att jobba naturligtvis men att man lär sej saker och ting. Jag känner mej priviligierad att få göra det, jag tycker det är jättekul. Det blir en liten sporre, en liten kick kan man väl säga. ...

Men personlig utveckling handlar inte bara om att vara priviligierad inom företaget. Processen har också resulterat i tankar om nya, möjliga yrkesbanor, det vill säga blivit en startpunkt för utveckling $i$ en ny riktning.

... så man inte går i samma fotspår, man kanske får lite andra idéer också vad man vill göra istället kanske. Så är det.

\section{Ett mönster i erfarenheterna}

Den kontextuella analysen av de internala relationerna mellan de kategorier som presenterats ovan visar på tre olika sätt att relatera sig själv som deltagare till valideringsinitiativet. Deltagarna gav uttryck för en utvecklingsinriktad relation, en meritinriktad relation och/eller ${ }^{3}$ en kritisk relation till processen, där de två första typerna av relationer kan jämföras med de utvecklingsinriktade och meritinriktade modellerna för validering (Butterworth, 1992). De olika typerna av relationer sammanfattas i tabell 1.

Den utvecklingsinriktade relationen betyder att validering huvudsakligen ses som ett tillfälle för personlig utveckling. Individen har gjorts medveten om kunskaper som han eller hon redan har. Valideringen relateras till såväl tidigare som nytt lärande. Processen har oavsiktligt resulterat i att nya idéer har utvecklats, exempelvis nya framtida yrkesplaner hos några av fastighetsskötarna. 
Deltagarna med denna relation till valideringen kan känna sig priviligierade, eftersom de är del av en mindre grupp medarbetare som har getts tillfälle att delta.

Tabell 1. Kännetecken på de olika sätten att relatera sig till valideringsinitiativet.

\begin{tabular}{|c|c|c|c|}
\hline & \multicolumn{3}{|c|}{ Typ av relation till validering } \\
\hline & Utvecklingsinriktad & Meritinriktad & Kritisk \\
\hline \multicolumn{4}{|l|}{ Erfarenheter av: } \\
\hline $\begin{array}{l}\text { Validerings- } \\
\text { processen }\end{array}$ & $\begin{array}{l}\text { Ett tillfälle för } \\
\text { personlig utveckling }\end{array}$ & $\begin{array}{l}\text { En fråga om } \\
\text { bedömning och } \\
\text { kontroll }\end{array}$ & $\begin{array}{l}\text { Bara skrapa på } \\
\text { ytan }\end{array}$ \\
\hline \multirow[t]{2}{*}{$\begin{array}{l}\text { Lärande i } \\
\text { validering }\end{array}$} & $\begin{array}{l}\text { Tidigare lärande } \\
\text { - } \quad \text { medvetenhet } \\
\text { - } \quad \text { uppfriskning }\end{array}$ & $\begin{array}{l}\text { Tidigare lärande } \\
\text { - } \quad \text { föremål för } \\
\text { bedömning och } \\
\text { kontroll }\end{array}$ & $\begin{array}{c}\text { Tidigare lärande } \\
\text { - } \quad \text { synliggjort i } \\
\text { begränsad } \\
\text { utsträckning }\end{array}$ \\
\hline & $\begin{array}{ll}\text { Nytt lärande } \\
\text { - } & \text { plocka upp saker } \\
\text { - } & \text { lära av andra } \\
\text { - } & \text { intresse och strä- } \\
& \text { van att lära mer } \\
\text { - } & \text { fortsatt } \\
& \text { kompetens- } \\
& \text { utveckling }\end{array}$ & $\begin{array}{l}\text { Nytt lärande } \\
-\quad \text { fortsatt } \\
\text { kompetens- } \\
\text { utveckling }\end{array}$ & $\begin{array}{l}\text { Inget nytt } \\
\text { lärande }\end{array}$ \\
\hline $\begin{array}{l}\text { Annat utbyte } \\
\text { av validering }\end{array}$ & $\begin{array}{ll}\text { Personlig utveckling } \\
\text { - } & \text { känna sig } \\
& \text { priviligierad } \\
- & \text { nya idéer }\end{array}$ & $\begin{array}{l}\text { Bytesvärde } \\
-\quad \text { certifiering } \\
-\quad \text { status }\end{array}$ & $\begin{array}{l}\text { Bytesvärde } \\
\text { - } \quad \text { för företaget } \\
\text { - } \quad \text { tveksamt för } \\
\text { mig }\end{array}$ \\
\hline
\end{tabular}

I den meritinriktade relationen ligger fokus däremot på bedömning och kontroll. Genom processen bedöms det tidigare lärandet. Detta kan ge tillfälle till fortsatt kompetensutveckling eller yrkesutbildning efter valideringsprocessen. Valideringen har ett bytesvärde, och fokus ligger på en meritinriktad relation till arbetsmarknaden och utbildningsmöjligheter.

Erfarenheten av att bara ha skrapat på ytan ligger slutligen till grund för en kritisk relation till processen. Det tidigare lärandet uppfattas bara ha gjorts synligt i begränsad utsträckning, och det finns ingen erfarenhet av att 
valideringsprocessen har lett till något nytt lärande. Värdet av ett "papper" ses som tveksamt. Valideringsinitiativet har möjligen ett värde för företaget, fastighetsbolaget, men troligen inte för en enskild anställd.

\section{Slutsatser}

Analysen har visat på en variation i erfarenheten av validering inom denna grupp av fastighetsskötare. Men den väcker också några mer allmänna frågor kring utvecklingen av validering som en del av olika system för (yrkes)utbildning, där satsningen på validering av fastighetsskötare fungerar som ett belysande exempel.

\section{Lärande bland fastighetsskötare}

Resultaten leder till flera reflektioner när det gäller den här specifika gruppen av yrkesmänniskor och deras relation till lärande. Jag tar därför här ett ämnes- eller disciplinspecifikt perspektiv (Breier, 2005) - eller här snarare ett yrkesspecifikt perspektiv. Som nämnts har fastighetsskötare traditionellt normalt lärt sig sitt yrke informellt, i arbetet. Detta är utgångspunkten för en tolkning av de olika erfarenheterna av lärande i validering, när det gäller sammanhanget för och sättet att lära.

Fastighetsskötare lär alltså normalt sett informellt, i det dagliga arbetet. Valideringssammanhanget är inte deras dagliga arbetssammanhang. En begränsad del av valideringen genomfördes visserligen på arbetsplatsen, men det är ändå inte det normala att man prövas och bedöms i det dagliga arbetet. Fastighetsskötarnas lärandesammanhang är således det dagliga arbetet, och valideringssammanhanget är inte det sammanhang där de brukar lära. Samtidigt är det så att de som ändå uppfattar att de lär sig saker till stor del gör detta genom att "snappa upp" saker. Detta är också deras normala sätt att lära i det dagliga arbetet, och det verkar rimligt att åtminstone vissa av dem fortsätter att ta till sig nya kunskaper på detta sätt även i valideringssammanhanget.

\section{Valideringens funktion och utveckling}

Ska och bör valideringsmodeller anpassas till eller sträva efter att förändra system? En meritinriktad modell är huvudsakligen anpassad till systemet - den har ett tekniskt/marknadsperspektiv. Bedömningen eller kontrollen utförs av representanter för systemet, det finns kriterier för vad som är accepterad kunskap och kompetens etc. Detta är grunden i den meritinriktade relation som har beskrivits ovan. Men det kan ändå finnas en potential för förändring även inom ramen för en meritinriktad modell. Bland deltagarna i det särskilda valideringsinitiativ där den här studien genomfördes, som formellt sett innebar en meritinriktad modell och resulterade i certifiering, fanns även det slags erfarenheter som har beskrivits 
ovan som en utvecklingsinriktad relation. Detta betyder att det fanns erfarenheter av "förändring" (utveckling), i varje fall på den individuella nivån.

Validering är - jämfört med traditionella bedömningsformer som skolans betyg och gesäll- och mästarprov i skrån och yrken - en ny form av kunskapsbedömning. Eller i varje fall är det ett nytt begrepp för bedömning och erkännande av "tidigare lärande", även om betygsättning och yrkesprövningar givetvis i en mening alltid har tagit hänsyn till det man har lärt sig tidigare. En konsekvens av att validering är något relativt nytt kan vara att det finns en öppenhet för förändring och nytänkande bland de som utvecklar valideringsmodeller. Alla initiativ inom det här området kan potentiellt tänkas skapa förändring, eftersom valideringsperspektivet innebär ett annat sätt att tänka om lärande och bedömning och vad som kan och borde bedömas, jämfört med ett utbildningsperspektiv där bedömningens fokus är det man har lärt inom ramen för en viss kurs. Visserligen står det exempelvis i den svenska läroplanen att man vid betygsättning ska ta hänsyn även till sådant som eleverna har lärt sig utanför undervisningen, men det är troligt att möjligheterna till detta övervägs på ett annat sätt när det finns en explicit valideringsdiskurs, när det finns ord för att tänka och tala i de banorna.

En utvecklingsinriktad modell kan vara ett tecken på en ambition att förändra systemet. De erfarenheter som fastighetsskötarna gav uttryck för och som tolkades som en utvecklingsinriktad relation till valideringen pekar på några centrala möjligheter. Att utveckla medvetenhet om ens befintliga kunskaper, att friska upp dessa, att snappa upp nya saker och att sträva efter att lära mer är exempel på vad som uppenbarligen kan vara delar av en valideringsprocess. I ett system där en meritinriktad modell för bedömning, exempelvis validering, dominerar finns därmed en potential för att förändra systemet i riktning mot ett mer utvecklingsinriktat förhållningssätt till bedömningen. Alternativt så förblir utvecklingsinriktningen begränsad till den individuella nivån, där förhållningssättet kan finnas oberoende av de officiella modellerna.

En central del i denna utvecklingsinriktade aspekt av validering är lärande. Relationen mellan lärande och validering är också viktig att diskutera. Olika organisationsformer för validering har kunnat identifieras, där validering organiseras som en separat process, som en formativ bedömning inför en kompletterande utbildning, eller som en process där valideringen flätas samman med lärande och studier (se t.ex. Andersson, 2007; Andersson, Hult \& Fejes, 2002). Ett utvecklingsinriktat angreppssätt borde innebära att relationen och integreringen mellan bedömning och lärande blir föremål för reflektion. Detta kan jämföras med den utbildningsmodell som kallas för problembaserat lärande, där studenternas tidigare lärande identifieras i början av lärprocessen och används som utgångspunkt för de organiserade studierna (se t.ex. Abrandt Dahlgren, 2001).

Den kritiska erfarenheten av validering "sticker ut" på ett intressant sätt. Här finns en osäkerhet kring kvaliteten i bedömningen, eller rentav en övertygelse 
om bristen på kvalitet. Poängen är att valideringen uppfattas som att den bara synliggör och bedömer en begränsad del av yrkeskompetensen, och på ett otillförlitligt sätt. I utvecklingen av validering är det viktigt att detta slag av kritiska erfarenheter kommer upp till ytan. En rimlig nivå på validitet och reliabilitet är nödvändig för att bedömningen ska få legitimitet - det vill säga att även om vi aldrig når fullständig validitet eller reliabilitet i kunskapsbedömningar så behöver nivån ändå vara tillräckligt hög för att inte resultaten ska ifrågasättas. Alla dessa aspekter - validitet, reliabilitet och legitimitet - är också nödvändiga för att utveckla tillit till valideringens idéer och praktiker (se även Bjørnåvold, 2000). Om vi vill att validering ska bli något som verkligen gör skillnad när det gäller vilket lärande och vilka kunskaper som faktiskt "räknas", och verkligen utnyttja den potential som finns i idén om validering, är kritiska perspektiv viktiga drivkrafter. Det ligger, till exempel, en viktig utmaning i att hitta sätt för att synliggöra det som finns "under ytan", i detta fall handlar det om yrkesspecifika valideringsmodeller som inte uppfattas som att man skrapar på ytan, utan snarare som att man identifierar vad du faktiskt kan och vet. En sådan process kan vara en fråga om lärande $i$ sig, likväl som en utgångspunkt för fortsatt utbildning och lärande.

\section{Slutnoter}

1 Studiens resultat har tidigare redovisats i en engelskspråkig version i Andersson (2006). 2 Med uttrycket "idealtyper" vill jag förtydliga att kategorierna inte är av det slag där varje individ endast kan relateras till en enstaka kategori. En deltagare kan tvärtom, till exempel, ha uttryckt ett sätt att erfara validering som innebär en kombination av två av de kategorier som kommer att presenteras.

${ }^{3}$ Kategorierna är fortfarande "idealtyper".

\section{Erkännande åt tidigare stöd i forskningsprocessen}

Den studie som ligger till grund för artikeln genomfördes inom ramen för ett projekt finansierat av Vetenskapsrådet. Framlidne professorn i pedagogik Lars Owe Dahlgren, Linköpings universitet, gav värdefulla råd kring den ursprungliga presentationen av den fenomenografiska ansatsen och studien.

\section{Om författaren}

Per Andersson är professor i pedagogik vid Linköpings universitet. Hans forskning har i stor utsträckning handlat om bedömning, med särskild fokus på validering av tidigare lärande. Andra forskningsområden är lärares arbete och professionella utveckling, med fokus på yrkeslärare och folkhögskollärare, samt vuxenutbildningens organisering och marknadisering. 


\section{Referenser}

Aagaard, K. \& Dahler, A.M. (Red.) (2011). Anerkendelse af realkompetencer - en antologi. Århus: Viasystime.

Abrandt Dahlgren, M. (2001). Portraits of PBL: A cross-faculty comparision of students' experiences of problem-based learning (Linköping Studies in Education and Psychology No. 80). Linköping: Linköpings universitet.

Andersson, P. (2006). Caretakers' experiences of RPL. Journal of Vocational Education and Training, 58(2), 115-133.

Andersson, P. (2007). Recognition of informal ICT competence. Nordic Journal of Digital Literacy [Digital Kompetanse], 2(3), 173-188.

Andersson, P. \& Fejes A. (2011). Sweden: The developing field of validation research. I J. Harris, M. Breier \& C. Wihak (Red.), Researching the Recognition of Prior Learning: International Perspectives (s. 228-247). Leicester: NIACE.

Andersson, P. \& Fejes, A. (2014). Svensk forskning om validering av vuxnas lärande - trender och tendenser. Pedagogisk Forskning $i$ Sverige, Tema: Bedömning och dokumentation, 19(4-5), 324-344.

Andersson, P. \& Harris, J. (Red.) (2006). Re-theorising the Recognition of Prior Learning. Leicester: NIACE.

Andersson, P., Hult, Å. \& Fejes, A. (2002). Validering av utländsk yrkeskompetens - en studie av den utökade försöksverksamheten. I Validering av utländsk yrkeskompetens, Redovisning av regeringsuppdrag, Dnr: 01-2001:03631, Bilaga 1. Stockholm: Skolverket.

Andersson, P., Sjösten, N-Å. \& Ahn, S-e. (2003). Att värdera kunskap, erfarenhet och kompetens: Perspektiv på validering (Forskning i fokus nr. 9). Stockholm: Myndigheten för skolutveckling,

Bjørnåvold, J. (2000). Making learning visible: Identification, assessment and recognition of non-formal learning in Europe. Tessaloniki: Cedefop - European Centre for the Development of Vocational Training.

Bowden, J.A. \& Walsh, E. (Red.) (1994). Phenomenographic research: Variations in method. The Warburton symposium. Melbourne: Royal Melbourne Institute of Technology.

Breier, M. (2005). A disciplinary-specific approach to the recognition of prior informal experience in adult pedagogy: 'rpl' as opposed to 'RPL'. Studies in Continuing Education, 27(1), 51-65.

Butterworth, C. (1992). More than one bite at the APEL: Contrasting models of accrediting prior learning. Journal of Further and Higher Education, 16(3), 39-51.

Halttunen, T., Koivisto, M. \& Billett, S. (Red.) (2014). Promoting, assessing, recognizing and certifying lifelong learning: International perspectives and practices. Dordrecht: Springer.

Harris, J., Breier, M. \& Wihak, C. (Red.) (2011). Researching the Recognition of Prior Learning: International perspectives. Leicester: NIACE. 
Harris, J., Wihak, C. \& Van Kleef, J. (Red.) (2014). Handbook of the Recognition of Prior Learning: Research into practice. Leicester: NIACE.

Hult, Å. \& Andersson, P. (2008). Validering i de nordiska länderna: policy och praktik. Kristianstad: fiora förlag / Nordiskt nätverk för vuxnas lärande (NVL).

Marton, F. (1981). Phenomenography - describing conceptions of the world around us. Instructional Science, 10(2), 177-200.

Marton, F. (1988). Phenomenography: A research approach to investigating different understandings of reality. I R.R. Sherman \& R.B. Webb (Red.) Qualitative research in education: Focus and methods (s. 141-161). London, New York, Philadelphia: The Falmer Press.

Marton, F. \& Booth, S. (1997). Learning and Awareness. Mahwah, New Jersey: Lawrence Erlbaum Associates, Publishers.

SOU 1996:27. En strategi för kunskapslyft och livslångt lärande. Stockholm: Regeringskansliet, Utbildningsdepartementet.

Svensson, L. (1976). Study Skill and Learning (Göteborg Studies in Educational Sciences 19). Göteborg: Acta Universitatis Gothoburgensis.

Torrance, H. \& Pryor, J. (1998). Investigating formative assessment. Buckingham: Open University Press.

Walsh, E. (1994). Phenomenographic analysis of interview transcripts. I J.A. Bowden \& E. Walsh (Red.) Phenomenographic research: Variations in method. The Warburton symposium (s. 17-30). Melbourne: Royal Melbourne Institute of Technology. 